\title{
Implementation of targeted temperature management after cardiac arrest in Polish intensive care units. What has changed in the last five years?
}

\author{
Paweł Krawczyk ${ }^{1}$, Anna Tarczyńska ${ }^{1}$, Grzegorz Dziadek ${ }^{1}$, Miłosz Gołębiowski ${ }^{1}$, \\ Andrzej A. Kononowicz ${ }^{2}$, Janusz Andres ${ }^{1}$ \\ 'Department of Anaesthesiology and Intensive Care, Jagiellonian University Medical College, Krakow, Poland \\ ${ }^{2}$ Department of Bioinformatics and Telemedicine, Jagiellonian University Medical College, Krakow, Poland
}

\begin{abstract}
Background: Studies conducted up to 2010 indicate the underuse of targeted temperature management (TTM) in Poland. Aim: This study evaluated the current degree of TTM implementation in Polish intensive care units (ICUs) and analysed the implementation process since 2010.

Methods: A telephone survey, conducted from December 2014 to July 2015, was carried out to determine the number of ICUs using TTM in patients after cardiac arrest. We collected data on the details and prevalence of TTM, and the impact of organisational and financial issues and recently published papers on its use.

Results: We obtained data from 271 of 396 ICUs (68.4\%). In total, 79 (29.2\%) ICUs indicated TTM use and 27 (34.2\%) used dedicated TTM equipment. Overall, $62 \%$ of the ICUs used TTM regardless of the cardiac arrest rhythm. Target temperatures of $32-34^{\circ} \mathrm{C}$ and $34.1-36^{\circ} \mathrm{C}$ were reached by $44.3 \%$ and $43.0 \%$ of ICUs, respectively. The duration of TTM was $12-24 \mathrm{~h}$ in $58.2 \%$ of the ICUs. The most common barriers to TTM implementation were a lack of dedicated devices (36.3\%) and organisational and logistical issues (31.2\%). Any influence of recently published data on TTM practice modifications was reported by only $23.4 \%$ of the ICUs.

Conclusions: Targeted temperature management is underused in Polish ICUs. There is a need for additional educational and implementation efforts supporting the translation of knowledge into clinical practice at the regional and national levels.

Key words: survey, therapeutic hypothermia, targeted temperature management, cooling, post-cardiac arrest care, cardiac arrest, guidelines implementation
\end{abstract}

Kardiol Pol 2017; 75, 7: 689-697

\section{INTRODUCTION}

Every year 350,000 people die in Europe due to cardiac arrest [1]. In 2002, two landmark publications showed improved neurological outcomes after the introduction of therapeutic hypothermia to post-cardiac arrest care [2, 3]. Since 2003 this therapy has been recommended by the International Liaison Committee on Resuscitation [4], and targeted temperature management (TTM) has been implemented as part of resuscitation guidelines [5-7]. Despite this recommendation,
TTM was not promptly adopted as a standard of care in every European country [8-10]. Nevertheless, data from Poland showed that growing numbers of intensive care units (ICUs) were using TTM - from $7.6 \%$ of ICUs in 2005 to $21.7 \%$ in 2010 [11, 12]. The aim of this study was to assess the current status of TTM use in Polish ICUs and the changes during a five-year period in TTM practices, and to study the impact of the results of two recent randomised controlled trials (RCTs) on TTM use. 


\section{METHODS}

Using the Polish National Registry of Operators Executing Medical Activity database [13], we identified 467 ICUs in Poland. From December 2014 to July 2015 we carried out a telephone survey, so the survey was conducted before the latest European Resuscitation Council 2015 guidelines were published [7].

Firstly, we contacted the consultant in charge of each ICU. In cases where there was no response to our first telephone call, we made at least two additional attempts at contact. The questionnaire employed in this study was based on an instrument used in previous studies [11, 12] and included 13 questions regarding the prevalence of TTM after cardiac arrest regardless its location, the number of patients cooled during the previous year, the TTM methodology used, data related to cardiac arrest circumstances, and any impact of recently published data on current TTM practice.

Statistical significance of differences was analysed using the R package v. 3.3.1 (R Foundation for Statistical Computing, 2016) [14], respectively, with Pearson's Chi-squared $\left(\chi^{2}\right)$ test and Fisher's exact test (FET). A significance level $\alpha$ of 0.05 was chosen.

The study protocol was approved by the Ethical Committee of Jagiellonian University (approval number: $\mathrm{KBET} / 265 / \mathrm{B} / 2014)$.

\section{RESULTS}

In total, 71 of the identified 467 ICUs were shown not to be ICUs treating patients after cardiac arrest; instead, they were anaesthesia departments that did not meet the inclusion criteria. We were able to make contact with 340 of the remaining 396 ICUs. Despite numerous attempts, we were unable to reach 56 ICUs. We obtained data from 271 units, representing a $68.4 \%(271 / 396)$ response rate. The main reason for missing data was a lack of willingness to participate in the study $(\mathrm{n}=69)$. We obtained information by e-mail in 15 cases because that contact modality was insisted on by the staff of those ICUs during the telephone survey (Fig. 1).

The total number of ICUs that declared TTM use was 79 (29.2\%). Figure 2 shows an administrative map of Poland and provides percentage values of ICUs using TTM by region. Table 1 shows distribution of the study responses in different regions of Poland.

In total, $53.2 \%$ of the ICUs declaring TTM use had employed the method in more than five patients during the previous year. Externally applied, non-invasive measures were most commonly used for cooling (e.g. ice bags and cooled gels) $(43.5 \%)$. The use of cold intravenous fluids for induction was also common (31.3\%). Few of the respondents (6.1\%) declared using cold fluids for gastric lavage or urinary bladder lavage. Dedicated cooling devices, which were either internal $(n=8)$ or external $(n=19)$, were used by $34.2 \%$ of the ICUs for the induction and maintenance hypothermia. An alterna-

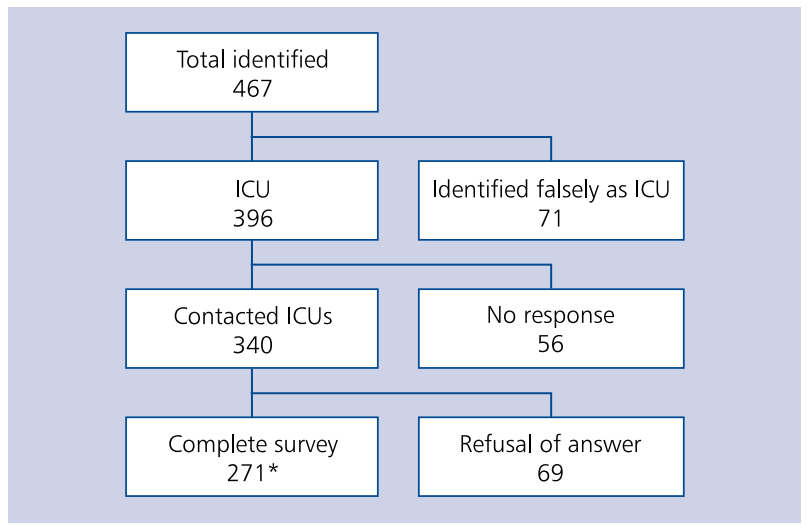

Figure 1. Study flowchart showing the number of intensive care units (ICUs) identified and included in the study; *Including 15 responses by e-mail

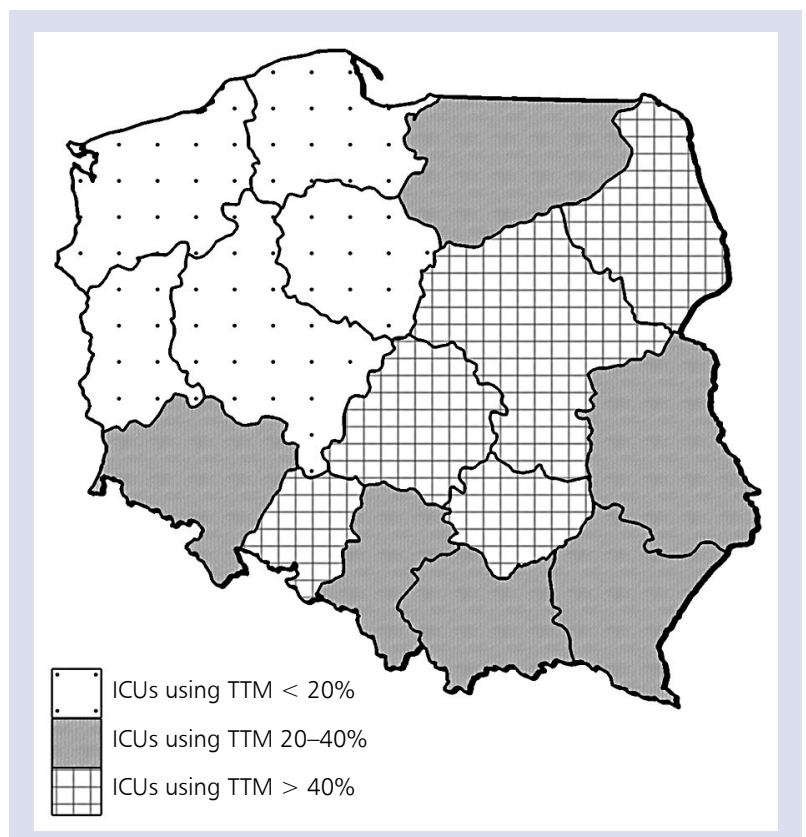

Figure 2. The percentage of Polish intensive care units (ICUs) using targeted temperature management (TTM) after cardiac arrest in 2015

tive method of cooling reported by one unit involved a renal replacement therapy device. In terms of target temperatures, the respondents differed somewhat; $44.3 \%$ targeted $32-34^{\circ} \mathrm{C}$, whereas $43.0 \%$ aimed at a higher temperature of $34.1-36^{\circ} \mathrm{C}$. Most of the ICUs (58.2\%) maintained TTM for 12-24 h; however, 30.4\% cooled their patients for more than $24 \mathrm{~h}$. The most common location of the temperature probe was in the oesophagus (40.0\%). The respondents did not use TTM for every return of spontaneous circulation patient $-62.0 \%$ 
Table 1. Distribution of the study responses in different regions of Poland

\begin{tabular}{|lccccc|}
\hline Voivodeship & $\begin{array}{c}\text { Total number } \\
\text { of ICUs }\end{array}$ & $\begin{array}{c}\text { Responding } \\
\text { ICUs }\end{array}$ & $\begin{array}{c}\text { Response } \\
\text { rate }\end{array}$ & $\begin{array}{c}\text { TTM use: } \\
\text { number of units }\end{array}$ & $\begin{array}{c}\text { TTM use } \\
\text { (\%) }\end{array}$ \\
\hline Lower Silesia & 35 & 25 & $71 \%$ & 6 & $24 \%$ \\
Kuyavia-Pomerania & 23 & 14 & $61 \%$ & 2 & $14 \%$ \\
Lublin & 23 & 15 & $65 \%$ & 4 & $27 \%$ \\
Lubus & 14 & 11 & $79 \%$ & 2 & $18 \%$ \\
Lodz & 29 & 17 & $59 \%$ & 7 & $41 \%$ \\
Lesser Poland & 36 & 24 & $67 \%$ & 7 & $29 \%$ \\
Masovia & 48 & 32 & $67 \%$ & 14 & $44 \%$ \\
Opole & 9 & 7 & $78 \%$ & 5 & $71 \%$ \\
Subcarpathia & 23 & 17 & $74 \%$ & 6 & $35 \%$ \\
Podlasie & 13 & 11 & $85 \%$ & 5 & $45 \%$ \\
Pomerania & 16 & 6 & $38 \%$ & 0 & $0 \%$ \\
Silesia & 39 & 24 & $62 \%$ & 5 & $21 \%$ \\
Holy Cross & 11 & 9 & $82 \%$ & 5 & $56 \%$ \\
Warmia-Masuria & 19 & 12 & $83 \%$ & 3 & $25 \%$ \\
Greater Poland & 36 & 31 & $73 \%$ & 5 & $16 \%$ \\
West Pomerania & 22 & 16 & 3 & $19 \%$ \\
\hline
\end{tabular}

ICUs — intensive care units; TTM — targeted temperature management

used TTM regardless of the cardiac arrest rhythm, and 27.9\% used TTM only in cases of cardiac arrest of shockable rhythm origin. Pre-hospital usage of TTM was declared by less than $4 \%$ of the respondents.

Almost half of the respondents declaring non-use of TTM planned to use it in the future. The most common barriers to implementation were, among other factors, a lack of dedicated equipment (36.3\%) and financial issues (23.3\%); however, only $13.9 \%$ of the respondents declaring TTM use stated that funding provided by the National Healthcare System for TTM positively impacted the frequency of its use.

The questionnaire also inquired about awareness of recently published data in the field of TTM (and where this could influence medical practice) $[15,16]$. Knowledge of these data was confirmed by $29.8 \%$ of the respondents; however, only $23.4 \%$ of those who declared TTM use changed their practice in response to the published results. Detailed results of the survey are presented in Table 2.

\section{DISCUSSION}

Our study indicates TTM underuse in Polish ICUs. Compared with previously published data, our results show that there has been progress in the number of Polish units treating their patients with $\operatorname{TTM}(7.6 \%, 21.7 \%$, and $29.2 \%$ of surveyed ICUs in 2005, 2010, and 2015, respectively; Fig. 3) [11, 12]. A recently published paper analysing TTM use among Italian ICUs also showed TTM underuse [17]; however, the increase in rate of TTM use in ICUs in Italy has exceeded that in Poland since 2005 (increases of $68 \%$ and $36.5 \%$ per year, respectively).

Table 3 compares the key elements of TTM in studies done in 2010 and 2015 in Poland. Due to the small sample size in 2005 it was not included in the analysis (Table 3).

Nevertheless, there have been some changes in the pattern of TTM use among Polish ICUs in the last five years. In 2010, almost half of Polish ICUs declaring use of TTM were treating more than 20 patients per year with TTM, compared to only $15 \%$ currently (Table $3 ; \chi^{2}, p<0.001$ ). This may have an impact on the TTM experience of the staff, and may be associated with patient outcome [18].

Currently, the distribution of hospital admissions for cardiac arrest patients varies among different regions of Poland. Poland is one of the leading European countries in terms of accessibility to cardiac catheterisation laboratory evaluations and continual improvement in patient outcomes [19, 20]. It is probable that many cardiac arrest patients (i.e. the potential beneficiaries of TTM) are preselected before hospital admission and transferred directly to cardiac catheterisation laboratory evaluation centres in cases of cardiac arrest of obvious cardiac origin. Hospital admission in such cases is followed by a coronary care unit stay; such units were beyond the scope of our study, and this may have decreased the reported actual use of TTM in Poland. However, the precise prevalence of this type of admission remains unknown. In our study, only ICUs staffed by anaesthetists were included. 
Table 2. Detailed results of the survey on the use of targeted temperature management in Polish intensive care units; *Units could report more than one answer

\begin{tabular}{|c|c|}
\hline 1. Do you use TTM after ROSC in your unit? & Proportion \\
\hline Yes & $29.2 \%(79 / 271)$ \\
\hline No & $70.8 \%(192 / 271)$ \\
\hline \multicolumn{2}{|c|}{ 2. How many patients did you cool after ROSC during the last year? } \\
\hline $1-5$ & $46.8 \%(37 / 79)$ \\
\hline $6-10$ & $25.3 \%(20 / 79)$ \\
\hline $11-20$ & $12.7 \%(10 / 79)$ \\
\hline$>20$ & $15.2 \%(12 / 79)$ \\
\hline \multicolumn{2}{|c|}{ 3. What methods (internal and/or external) do you use to induce and maintain TTM?* } \\
\hline \multicolumn{2}{|l|}{ Internal } \\
\hline Cold intravenous fluids & $31.3 \%(46 / 147)$ \\
\hline Dedicated devices for internal cooling & $5.5 \%(8 / 147)$ \\
\hline Gastric or bladder lavage with cold fluids & $6.1 \%(9 / 147)$ \\
\hline Cold dialysis fluid & $0.7 \%(1 / 147)$ \\
\hline \multicolumn{2}{|l|}{ External } \\
\hline Cold packing (ice bags, cooled gels) & $43.5 \%(64 / 147)$ \\
\hline Dedicated devices for external cooling & $12.9 \%(19 / 147)$ \\
\hline \multicolumn{2}{|l|}{ 4. What is your target temperature during TTM? } \\
\hline $30-31.9^{\circ} \mathrm{C}$ & $1.3 \%(1 / 79)$ \\
\hline $32-34^{\circ} \mathrm{C}$ & $44.3 \%(35 / 79)$ \\
\hline $34.1-35.9^{\circ} \mathrm{C}$ & $38.0 \%(30 / 79)$ \\
\hline $36^{\circ} \mathrm{C}$ & $5.0 \%(4 / 79)$ \\
\hline No control & $11.4 \%(9 / 79)$ \\
\hline \multicolumn{2}{|c|}{ 5. At what location is the temperature measured during TTM?* } \\
\hline Oesophagus & $40.0 \%(36 / 90)$ \\
\hline Rectum & $22.2 \%(20 / 90)$ \\
\hline Invasive catheter & $8.9 \%(8 / 90)$ \\
\hline Tympanic & $6.7 \%(6 / 90)$ \\
\hline Urinary bladder & $7.8 \%(7 / 90)$ \\
\hline Body surface & $5.5 \%(5 / 90)$ \\
\hline No control & $8.9 \%(8 / 90)$ \\
\hline \multicolumn{2}{|l|}{ 6. What is the duration of TTM? } \\
\hline$<12 \mathrm{~h}$ & $11.4 \%(9 / 79)$ \\
\hline $12-24 \mathrm{~h}$ & $58.2 \%(46 / 79)$ \\
\hline$>24 \mathrm{~h}$ & $30.4 \%(24 / 79)$ \\
\hline \multicolumn{2}{|c|}{ 7. What cardiac arrest rhythms do you consider when selecting patients for TTM? } \\
\hline All rhythms & $62.0 \%(49 / 79)$ \\
\hline Non-shockable rhythms only (PEA/asystole) & $10.1 \%(8 / 79)$ \\
\hline Shockable rhythms only (VT/VF) & $27.9 \%(22 / 79)$ \\
\hline \multicolumn{2}{|l|}{ 8. Do you perform pre-hospital TTM? } \\
\hline Yes & $3.8 \%(3 / 79)$ \\
\hline No & $96.2 \%(76 / 79)$ \\
\hline \multicolumn{2}{|c|}{ 9. Have changes in TTM funding impacted the frequency of your TTM use? } \\
\hline Yes & $13.9 \%(11 / 79)$ \\
\hline No & $86.1 \%(68 / 79)$ \\
\hline
\end{tabular}


Table 2. cont. Detailed results of the survey on the use of targeted temperature management in Polish intensive care units; *Units could report more than one answer

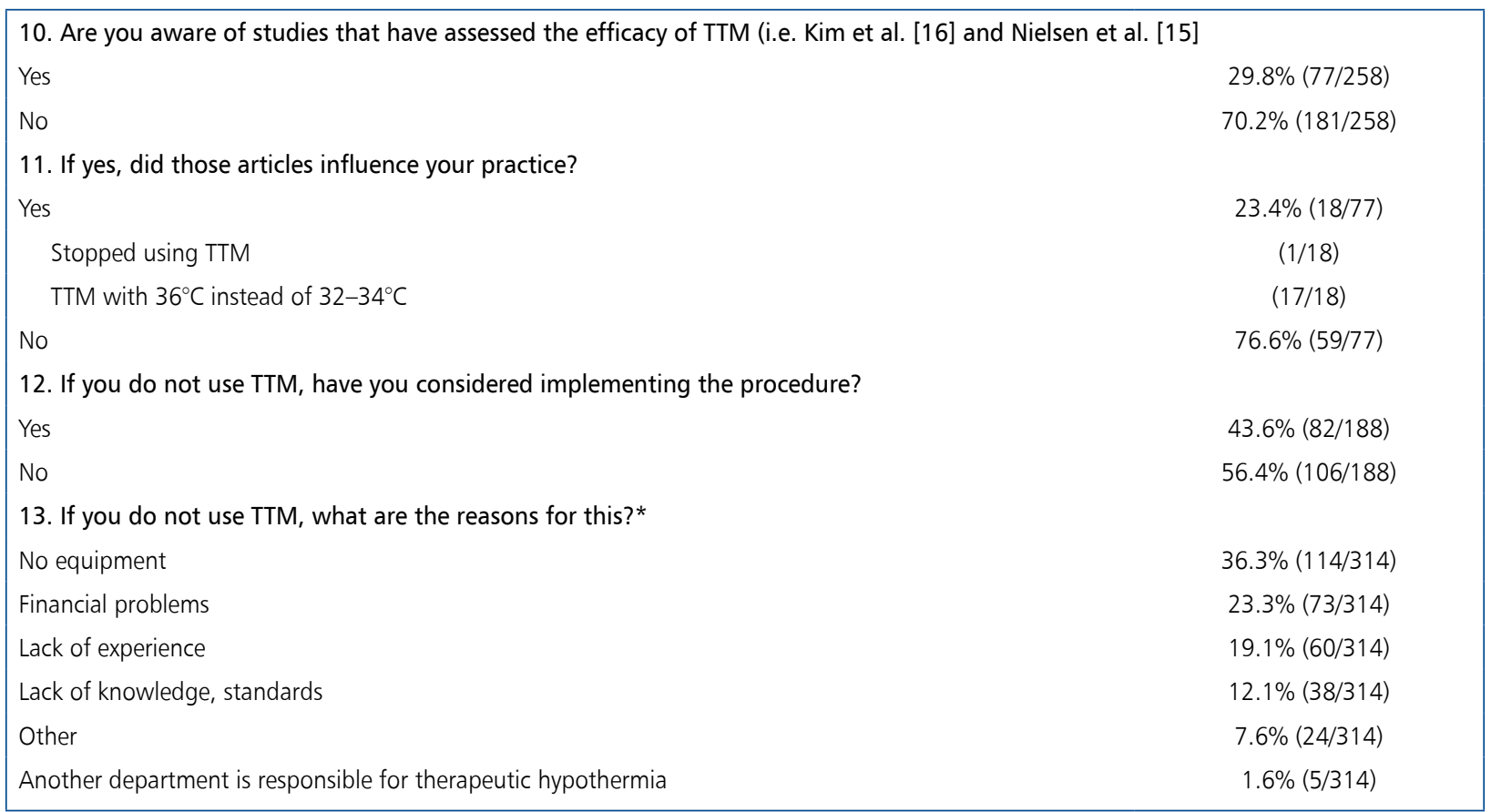

PEA — pulseless electrical activity; ROSC — return of spontaneous circulation; VF/VT — ventricular fibrillation/ventricular tachycardia

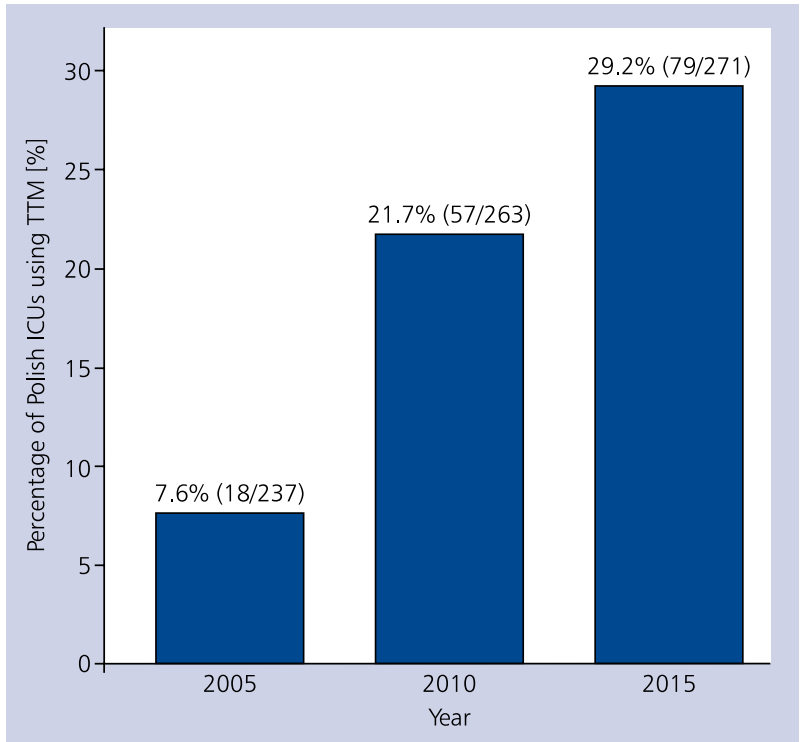

Figure 3. The percentage of Polish intensive care units (ICUs) using targeted temperature management (TTM) in 2005-2015

In our study, the distribution of TTM sites in Poland also differed compared to a previous study [12]. In the majority of regions, TTM use had increased. However, there was an unequal distribution of ICUs using TTM within the country, with greater TTM use in central and eastern Poland; regional differences have also been described in Italy. Our data show the regions that should be targeted with respect to improved dissemination of post-resuscitation management knowledge and awareness of current recommendations.

Overall, 27 (34.2\%) ICUs used dedicated devices providing either internal (8/79, 10.2\%) or external (19/79, 24.0\%) cooling. This represents a major change compared with a 2010 assessment, during which no ICU declared use of equipment for internal cooling and only 9\% (5/57) used dedicated external TTM devices (Table 3; $\chi^{2}, p<0.001$ ). However, 34.2\% remains a very low proportion when compared with recently published studies from Italy or Germany that demonstrated the use of dedicated TTM equipment in $75 \%$ and $78 \%$ of cases, respectively $[17,21]$. The most popular methods of cooling in Polish ICUs are cold intravenous fluids for induction and ice packs for maintenance. Similar to the Italian study [17], 36\% of our respondents cited lack of equipment as the reason for not using TTM. There is no contraindication for using TTM without specific equipment; despite more precise temperature control, reduced latency in reaching the target temperature (when $32-34^{\circ} \mathrm{C}$ is chosen as the target), and less nursing staff workload, there is no evidence of better patient outcomes when using dedicated equipment [22, 23].

Our analysis of the reasons for not cooling patients showed similar results to a previous study (lack of protocols, equipment, and experience, and problems with funding) [12]. In 2014, the Polish National Healthcare System started 
Table 3. Comparison of the key targeted temperature management (TTM) elements found in the 2010 and 2015 studies. Due to the small sample size of the 2005 study, it was not included

\begin{tabular}{|c|c|c|c|c|c|}
\hline Question & Answer & 2010 & 2015 & Test & p \\
\hline \multirow[t]{2}{*}{ 1. Do you use TTM after ROSC in your units? } & Yes & $57(22 \%)$ & $79(29 \%)$ & \multirow[t]{2}{*}{$\mathrm{Chi}^{2}$} & \multirow[t]{2}{*}{0.047} \\
\hline & No & $206(78 \%)$ & $192(71 \%)$ & & \\
\hline \multirow{2}{*}{$\begin{array}{l}\text { 2. How many patients did you cool after ROSC } \\
\text { during the last year? }\end{array}$} & $<20$ & $32(56 \%)$ & $67(85 \%)$ & \multirow[t]{2}{*}{$\mathrm{Chi}^{2}$} & \multirow[t]{2}{*}{$<0.001$} \\
\hline & $>20$ & $25(44 \%)$ & $12(15 \%)$ & & \\
\hline \multirow{2}{*}{$\begin{array}{l}\text { 3. Do you use dedicated devices } \\
\text { for cooling? }\end{array}$} & Device & $5(9 \%)$ & $27(34 \%)$ & \multirow[t]{2}{*}{$\mathrm{Chi}^{2}$} & \multirow[t]{2}{*}{$<0.001$} \\
\hline & No device & $52(91 \%)$ & $52(66 \%)$ & & \\
\hline \multirow{2}{*}{$\begin{array}{l}\text { 4. What is your target temperature } \\
\text { during TTM? }\end{array}$} & $32-34^{\circ} \mathrm{C}$ & $37(65 \%)$ & $35(51 \%)$ & \multirow[t]{2}{*}{$\mathrm{Chi}^{2}$} & \multirow[t]{2}{*}{0.11} \\
\hline & $>34^{\circ} \mathrm{C}$ & $20(35 \%)$ & $34(49 \%)$ & & \\
\hline \multirow[t]{3}{*}{ 6. What is the duration of TTM? } & $<12 \mathrm{~h}$ & $6(11 \%)$ & $9(11 \%)$ & \multirow[t]{3}{*}{$\mathrm{Chi}^{2}$} & \multirow[t]{3}{*}{0.84} \\
\hline & $12-24 \mathrm{~h}$ & $36(63 \%)$ & $46(58 \%)$ & & \\
\hline & $>24 \mathrm{~h}$ & $15(26 \%)$ & $24(30 \%)$ & & \\
\hline \multirow{2}{*}{$\begin{array}{l}\text { 7. Do you consider all cardiac arrest rhythms } \\
\text { when selecting patients for TTM? }\end{array}$} & All rhythms & $55(98 \%)$ & $49(69 \%)$ & \multirow[t]{2}{*}{ FET } & \multirow[t]{2}{*}{$<0.001$} \\
\hline & VF/NT & $1(2 \%)$ & $22(31 \%)$ & & \\
\hline \multirow[t]{2}{*}{ 8. Do you perform pre-hospital TTM? } & Yes & $2(4 \%)$ & $3(4 \%)$ & \multirow[t]{2}{*}{ FET } & \multirow[t]{2}{*}{1} \\
\hline & No & $55(96 \%)$ & $76(96 \%)$ & & \\
\hline
\end{tabular}

FET — Fisher's exact test; ROSC — return of spontaneous circulation; VFNT — ventricular fibrillation/ventricular tachycardia

to reimburse ICUs for the use of TTM. The economic aspects associated with introducing TTM have been discussed in other studies; however, in those studies, cost appeared also to not represent a major barrier to use [17].

Other reasons indicated in previous studies for ICUs not using TTM include a lack of ready-to-use protocols and a lack of strong evidence of the effectiveness of TTM from prospective, high-quality RCTs. Therefore, some clinicians remain unconvinced regarding the use of TTM in all cardiac arrest patients. This issue has been previously discussed elsewhere [24]. The recently updated Cochrane review on hypothermia for neuroprotection in adults after cardiopulmonary resuscitation, comparing conventional cooling versus no cooling, revealed a greater likelihood of reaching a favourable neurological outcome and survival benefit with cooling; however, it was also connected with increased incidence of pneumonia and hypokalaemia [25]. A recently published systematic review also indicated improved survival and neuroprotective benefit when exploring the impact of expended criteria and targeted temperature but did not find evidence to support one specific temperature over another [26].

Returning to the results of our study, we noted a risk of ICU staff misinterpreting recently published data. The study respondents were asked if they were aware of the results of the TTM trial [15]; only $29.8 \%$ declared familiarity with that trial, and some of them interpreted the results as supporting their hesitancy to use TTM. We identified at least one unit in which clinicians stopped using TTM because they misinterpreted the results of this previous trial. This is a current topic of discussion in the literature; misinterpretation of data creates the risk of TTM not being used, which may in turn influence patient outcomes [27]. Only $23.4 \%$ of our respondents with knowledge of the previous TTM trial [15] implemented the new evidence in their clinical practice with respect to current target temperature guidelines $\left(32-34^{\circ} \mathrm{C}\right.$ and $\left.36^{\circ} \mathrm{C}\right)$. A recent study of the influence of the TTM trial on the clinical practice of 264 ICUs in 11 countries showed that only $37 \%$ of the participating physicians declared changing any aspect of their practice [28]. This may be due to a generally low rate of translation of knowledge into clinical practice, and to a lack of strong published evidence on certain aspects of TTM.

Targeted temperature management use prior to hospitalisation is uncommon in Poland, being reported by only a few ICUs. The frequency of pre-hospital TTM use over the last 10 years has remained steady in Poland, with approximately $4 \%$ of units reporting this type of treatment $[11,12]$ (Table 3 ; FET, $p=1$ ). The therapeutic window for introducing TTM is up to $240 \mathrm{~min}$ [22]. Some studies indicate a potential benefit from early cooling [29]. However, recently published data by Kim et al. [16] did not demonstrate a significant difference in patient outcome when cold fluid infusion was introduced early. According to evidence coming from systematic review and meta-analysis on pre-hospital induction of hypothermia with cold fluid infusion, the patients had lower temperature at hospital admission without other benefits in survival and neurological outcome. The results indicate also increased incidence of rearrests, but there was no increase in pulmonary oedema rate reported in some studies [30].

\section{Limitations of the study}

One limitation of our study is the number of respondents; despite multiple attempts, we were unable to make contact 
with all of the ICUs. The refusal rate was $17.4 \%$ (69/396); despite this, we managed to reach a response rate of $68.4 \%$, with only one region having lower response rate, as shown in Table 1. Issues cited by the respondents included the fact that the survey had to be completed during working hours, as well as difficulties in maintaining telephone contact with personnel on active duty. However, we considered this mode of contact to be optimal for ensuring a high response rate compared to other methods (e.g. e-mail and postal mail correspondence). Nevertheless, telephone contact may also create bias although the respondents were consultant physicians in charge of the unit on the day of the call, such that the results should have been representative of the overall ICU. Finally, we did not collect additional information on post-cardiac arrest care (e.g. regarding the presence or absence of written standard operating procedures for treatment and prognosis, target haemodynamic values, and the use of ventilation, coronary interventions, and drugs), which may hinder full understanding of standard post-cardiac arrest care in Polish ICUs. However, this study aimed to specifically assess TTM use.

\section{CONCLUSIONS}

Based on the observations presented above, we conclude that despite an increase in the number of ICUs in Poland using TTM the method remains underused. There are no financial barriers to TTM implementation; instead, the major limitations include a persistent lack of national and regional standard TTM protocols, misunderstanding or misinterpretation of published evidence, and a lack of unequivocal data on TTM efficacy, which may influence current practice and patient outcomes. There is a need for increased educational and implementation efforts, to ensure clinical practice compliance with the guidelines at the national and regional levels to enhance the recovery of patients after cardiac arrest.

\section{Acknowledgements}

The authors thank all of the respondents for their participation in this study.

\section{Conflict of interest: none declared}

\section{References}

1. Böttiger BW, Van Aken HK. Saving 100,000 lives each year in Europe. Best Pract Res Clin Anaesthesiol. 2013; 27(3): 291-292, doi: 10.1016/j.bpa.2013.08.001, indexed in Pubmed: 24054507.

2. Hypothermia after Cardiac Arrest Study Group. Mild therapeutic hypothermia to improve the neurologic outcome after cardiac arrest. N Engl J Med. 2002; 346(8): 549-556, doi: 10.1056/NEJMoa012689, indexed in Pubmed: 11856793.

3. Bernard SA, Gray TW, Buist MD, et al. Treatment of comatose survivors of out-of-hospital cardiac arrest with induced hypothermia. N Engl J Med. 2002; 346(8): 557-563, doi: 10.1056/NEJMoa003289, indexed in Pubmed: 11856794.

4. Nolan JP, Morley PT, Hoek TL, et al. Therapeutic hypothermia after cardiac arrest. An advisory statement by the Advancement Life support Task Force of the International Liaison committee on Resuscitation. Resuscitation. 2003; 57(3): 231-235, indexed in Pubmed: 12858857.

5. Nolan JP, Deakin CD, Soar J, et al. European Resuscitation Council. European Resuscitation Council guidelines for resuscitation 2005. Section 4. Adult advanced life support. Resuscitation. 2005; 67 Suppl 1: S39-S86, doi: 10.1016/j.resuscitation.2005.10.009, indexed in Pubmed: 16321716.

6. Deakin CD, Nolan JP, Soar J, et al. European Resuscitation Council Guidelines for Resuscitation 2010 Section 4. Adult advanced life support. Resuscitation. 2010; 81(10): 1305-1352, doi: 10.1016/j. resuscitation.2010.08.017, indexed in Pubmed: 20956049.

7. Monsieurs KG, Nolan JP, Bossaert LL, et al. European Resuscitation Council Guidelines for Resuscitation 2015: Section 1. Executive summary. Resuscitation. 2015; 95: 1-80, doi: 10.1016/j. resuscitation.2015.07.038, indexed in Pubmed: 26477410.

8. Wolfrum S, Radke PW, Pischon T, et al. Mild therapeutic hypothermia after cardiac arrest - a nationwide survey on the implementation of the ILCOR guidelines in German intensive care units. Resuscitation. 2007; 72(2): 207-213, doi: 10.1016/j. resuscitation.2006.06.033, indexed in Pubmed: 17097795.

9. Bianchin A, Pellizzato N, Martano L, et al. Therapeutic hypothermia in Italian intensive care units: a national survey. Minerva Anestesiol. 2009; 75(6): 357-362, indexed in Pubmed: 19088699.

10. Laver SR, Padkin A, Atalla A, et al. Therapeutic hypothermia after cardiac arrest: a survey of practice in intensive care units in the United Kingdom. Anaesthesia. 2006; 61(9): 873-877, doi: 10 .1111/j.1365-2044.2006.04552.x, indexed in Pubmed: 16922754.

11. Krawczyk P, Fraczek B, Drab E. Use of therapeutic hypothermia in Polish intensive care units. Resuscitation. 2008; 79(2): 339, doi: 10.1016/j.resuscitation.2008.07.002, indexed in Pubmed: 18805619 .

12. Krawczyk P, Kołodziej G, Szpyra B, et al. Implementation of therapeutic hypothermia after cardiac arrest in intensive care units in Poland. Kardiol Pol. 2013; 71(3): 270-274, doi: 10.5603/KP.2013.0040, indexed in Pubmed: 23575783.

13. Polish registry of operators executing medical activity. . https:// rpwdl.csioz.gov.pl (Accessed 24 November 2015).

14. R Core Team (2016). R: A language and environment for statistical computing. R Foundation for Statistical Computing, Vienna, Austria. https://www.R-project.org/ (Accessed 21 August 2016).

15. Nielsen N, Wetterslev J, Cronberg T, et al. Targeted temperature management at $33^{\circ} \mathrm{C}$ versus $36^{\circ} \mathrm{C}$ after cardiac arrest. N Engl J Med. 2013; 369(23): 2197-2206, doi: 10.1056/nejmoa1310519.

16. Kim F, Nichol G, Maynard C, et al. Effect of prehospital induction of mild hypothermia on survival and neurological status among adults with cardiac arrest. JAMA. 2014; 311(1): 45-52, doi: 10.1001/jama.2013.282173.

17. Gasparetto N, Scarpa D, Rossi S, et al. Therapeutic hypothermia in Italian Intensive Care Units after 2010 resuscitation guidelines: still a lot to do. Resuscitation. 2014; 85(3): 376-380, doi: 10.1016/j. resuscitation.2013.11.014, indexed in Pubmed: 24300012.

18. Greif R, Lockey AS, Conaghan P, et al. European Resuscitation Council Guidelines for Resuscitation 2015: Section 10. Education and implementation of resuscitation. Resuscitation. 2015; 95: 288-301, doi: 10.1016/j.resuscitation.2015.07.032, indexed in Pubmed: 26477418.

19. Widimsky P, Wijns W, Fajadet J, et al. Reperfusion therapy for ST elevation acute myocardial infarction in Europe: description of the current situation in 30 countries. Eur Heart J. 2010; 31(8): 943-957, doi: 10.1093/eurheartj/ehp492, indexed in Pubmed: 19933242

20. Zeliaś A, Stępińska J, Andres J, et al. Ten-year experience of an invasive cardiology centre with out-of-hospital cardiac arrest patients admitted for urgent coronary angiography. Kardiol Pol. 2014; 72(8): 687-699, doi: 10.5603/KP.a2014.0088, indexed in Pubmed: 24846357. 
21. Storm C, Meyer T, Schroeder T, et al. Use of target temperature management after cardiac arrest in Germany: a nationwide survey including 951 intensive care units. Resuscitation. 2014; 85(8): 1012-1017, doi: 10.1016/j.resuscitation.2014.04.023, indexed in Pubmed: 24791691.

22. Nolan JP, Soar J, Cariou A, et al. European Resuscitation Council. European Resuscitation Council and European Society of Intensive Care Medicine 2015 guidelines for post-resuscitation care. Intensive Care Med. 2015; 41(12): 2039-2056, doi: 10.1007/s00134015-4051-3, indexed in Pubmed: 26464394.

23. Deye N, Cariou A, Girardie P, et al. Endovascular Versus External Targeted Temperature Management for Patients With Out-of-Hospital Cardiac Arrest: A Randomized, Controlled Study. Circulation. 2015; 132(3): 182-193, doi: 10.1161/CIRCULATIONAHA.114.012805, indexed in Pubmed: 26092673.

24. Hessel EA. Therapeutic hypothermia after in-hospital cardiac arrest: a critique. J Cardiothorac Vasc Anesth. 2014; 28(3): 789-799, doi: 10.1053/j.jvca.2014.01.015, indexed in Pubmed: 24751488.

25. Arrich J, Holzer M, Havel C, et al. Hypothermia for neuroprotection in adults after cardiopulmonary resuscitation. Cochrane Database Syst Rev. 2016; 2: CD004128, doi: 10.1002/14651858. CD004128.pub4, indexed in Pubmed: 26878327.
26. Schenone AL, Cohen A, Patarroyo G, et al. Therapeutic hypothermia after cardiac arrest: A systematic review/meta-analysis exploring the impact of expanded criteria and targeted temperature. Resuscitation. 2016; 108: 102-110, doi: 10.1016/j.resuscitation.2016.07.238, indexed in Pubmed: 27521472.

27. Targeted temperature management after cardiac arrest. N Engl J Med. 2014; 370(14): 1356-1361, doi: 10.1056/nejmc1401250.

28. Deye N, Vincent F, Michel P, et al. SRLF Trial Group. Changes in cardiac arrest patients' temperature management after the 2013 "TTM" trial: results from an international survey. Ann Intensive Care. 2016; 6(1): 4, doi: 10.1186/s13613-015-0104-6, indexed in Pubmed: 26753837.

29. Castrén M, Nordberg P, Svensson L, et al. Intra-arrest transnasal evaporative cooling: a randomized, prehospital, multicenter study (PRINCE: Pre-ROSC IntraNasal Cooling Effectiveness). Circulation. 2010; 122(7): 729-736, doi: 10.1161/CIRCULATIONAHA.109.931691, indexed in Pubmed: 20679548.

30. Nie C, Dong J, Zhang P, et al. Prehospital therapeutic hypothermia after out-of-hospital cardiac arrest: a systematic review and meta-analysis. Am J Emerg Med. 2016; 34(11): 2209-2216, doi: 10.1016/j.ajem.2016.09.007, indexed in Pubmed: 27658332

Cite this article as: Krawczyk P, Tarczyńska A, Dziadek G, et al. Implementation of targeted temperature management after cardiac arrest in Polish intensive care units. What has changed in the last five years? Kardiol Pol. 2017; 75(7): 689-697, doi: 10.5603/KP.a2017.0073. 


\title{
Implementacja kontroli temperatury docelowej po zatrzymaniu krążenia na polskich oddziałach intensywnej terapii. Co się zmieniło w ciągu ostatnich 5 lat?
}

\author{
Paweł Krawczyk ${ }^{1}$, Anna Tarczyńska ${ }^{1}$, Grzegorz Dziadek ${ }^{1}$, Miłosz Gołębiowski ${ }^{1}$, \\ Andrzej A. Kononowicz ${ }^{2}$, Janusz Andres ${ }^{1}$ \\ 'Katedra Anestezjologii i Intensywnej Terapii, Uniwersytet Jagielloński, Collegium Medicum, Kraków \\ 2Zakład Bioinformatyki i Telemedycyny, Uniwersytet Jagielloński, Collegium Medicum, Kraków
}

\section{Streszczenie}

Wstęp: Przeprowadzone do 2010 r. prace naukowe wskazują na niedostateczne stosowanie kontroli temperatury docelowej w Polsce.

Cel: Celem pracy była ocena częstości stosowania kontroli temperatury docelowej na polskich oddziałach anestezjologii i intensywnej terapii (OAilT) i analiza procesu implementacji od $2010 \mathrm{r}$.

Metody: Od grudnia 2014 do lipca 2015 r. przeprowadzono ankietę telefoniczną, aby ocenić liczbę OAilT w Polsce stosujących kontrolę temperatury docelowej u pacjentów po zatrzymaniu krążenia. Zbierano szczegółowe dane dotyczące samej procedury oraz wpływu zmian organizacyjnych, ostatnio opublikowanych dowodów naukowych na zastosowanie tej terapii. Wyniki: Uzyskano dane z 271 spośród 396 (68,4\%) OAilT. Stosowanie kontroli temperatury docelowej zadeklarowało $79(29,2 \%)$ OAilT, a $27(34,2 \%)$ z nich stosowało w tym celu dedykowany sprzęt. W 62\% OAilT stosowano kontrolę temperatury docelowej niezależnie od mechanizmu zatrzymania krążenia. Temperatury docelowe $32-34^{\circ} \mathrm{C}$ i $34,1-36^{\circ} \mathrm{C}$ były stosowane odpowiednio w $44,3 \%$ oraz $43,0 \%$ OAilT. Czas trwania procedury wynosił $12-24$ godzin w przypadku 58,2\% OAilT. Najczęstsze bariery stanowił brak sprzętu $(36,3 \%)$ oraz kwestie organizacyjne i logistyczne $(31,2 \%)$. Jedynie $23,4 \%$ OAilT zgłosiło modyfikacje w postępowaniu wynikające z niedawno opublikowanych danych.

Wnioski: Kontrola temperatury docelowej jest nadal rzadko stosowana na polskich OAilT. Istnieje duża potrzeba działań edukacyjnych w celu poprawy implementacji wytycznych w tym zakresie na poziomie regionalnym i krajowym.

Słowa kluczowe: ankieta, hipotermia terapeutyczna, kontrola temperatury docelowej, opieka poresuscytacyjna, zatrzymanie krążenia, Implementacja wytycznych

Kardiol Pol 2017; 75, 7: 689-697 